\title{
College and University Library Buildings: A Ten-Year Forecast, 1950-1960
}

$\mathrm{Mr}$. Stallings is librarian, North $\mathrm{Da}$ kota Agricultural College, Fargo.

\section{$\mathrm{T}$} HE ACRL Buildings Committee has made two studies on college and university library buildings recently. Three reports on the first study, issued by the chairman, Dr. Robert H. Muller, have appeared in College and Research Libraries. ${ }^{1}$ The information on future library buildings, reported on by Dr. Muller, was limited to IO3 libraries of accredited institutions. The information collected on a small scale seemed to justify a more exhaustive second survey of some 1860 colleges and universities in the United States, as listed in the United States Office of Education Directory, 1950-5I.

A questionnaire consisting of twelve questions was prepared by the committee and mailed to these 1860 colleges and universities. As of August 15, I95 I, there had been received 1555 , or 84.6 percent of the returns. (A few are still coming in). A complete report on the returns is expected to be published later. The present report is presented now because it contains timely information on the buildings to be built in the near future or buildings completed within the past year or so.

According to the findings in Question Io of the questionnaire, Ioo libraries are planning to build before 1960 , or have completed during the past year. Although

\footnotetext{
${ }^{1}$ October 1950 ; January \& July 1951.
}

many of the libraries listed here were on Dr. Muller's list in the January issue of College and Research Libraries, very few have listed the same estimated cost. For example, the University of Indiana jumped their estimate from $\$ 4,000,000$ to $\$ 6,000$,000 , and increased the capacity from $\mathrm{I}, 000,000$ to $\mathrm{I}, 500,000$ volumes, and seats from 2,000 to 2,800. The University of Pennsylvania changed their estimated cost from $\$ 2,000,000$ to $\$ 6,000,000$, and changed their capacity from 600,000 to 2,000,000 volumes. Many other changes in thinking in just a few months' time show up by comparing the two lists.

Some libraries are on Dr. Muller's list but did not answer the questionnaire for this compilation. For instance, the University of Chicago appears on the Muller list as proposing a $\$ 6,000,000$ building, but not on this list, since they did not answer the questionnaire. Thus a comparison of both lists is necessary to obtain a complete story. It is interesting to note that of the I03 libraries planning a new building, 29 of them plan to spend over a million dollars, ${ }_{5} 5$ of them over two million, and 2 of them as much as 6 million. The other 74 libraries will cost between $\$ 50,000$ and $\$ \mathrm{I}, 000,000$, with the median construction price at about $\$ 500,000$.

A brief summary of the other questions on the questionnaire is as follows:

Question I: "Does your library occupy a separate main building?"

$$
\text { Yes } 590 \quad \text { No } 846
$$


LIBRARIES COMPLETED OR TO BE COMPLETED 1950-1960

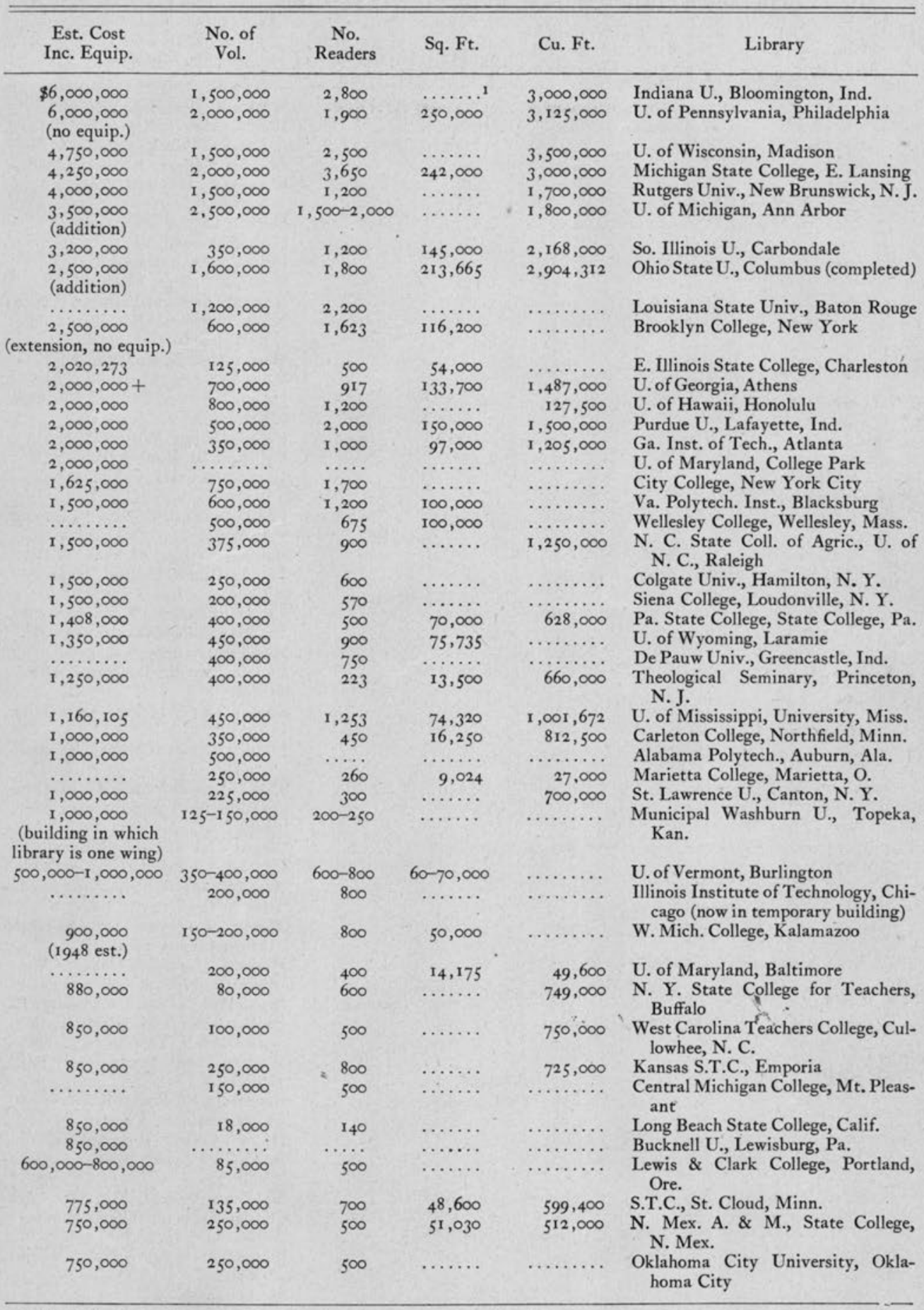

${ }^{1}$ A blank indicates that no information was given on the questionnaire. 
LIBRARIES COMPLETED OR TO BE COMPLETED 1950-1960-(continued)

\begin{tabular}{|c|c|c|c|c|c|}
\hline $\begin{array}{l}\text { Est. Cost } \\
\text { Inc. Equip. }\end{array}$ & $\begin{array}{l}\text { No. of } \\
\text { Vol. }\end{array}$ & $\begin{array}{c}\text { No. } \\
\text { Readers }\end{array}$ & Sq. Ft. & Cu. Ft. & Library \\
\hline 750,000 & $250, \infty 00$ & 287 & 14,621 & & Kenyon College, Gambier, O. \\
\hline $750, \infty 00$ & $150, \infty 00$ & 600 & $39, \infty 00$ & $\ldots \ldots \cdots$ & U. of California, Riverside \\
\hline $750, \infty 00$ & 125,000 & 400 & $\cdots \cdots$ & $\cdots \cdots \cdots$ & E. Carolina College, Greenville, N. C' \\
\hline 750,000 & 125,000 & 340 & $\ldots \ldots$ & $\cdots \cdots \cdots$ & Goucher College, Baltimore, Md. \\
\hline $500,000-750,000$ & $200, \infty 00$ & $500-600$ & $\cdots \cdots$ & 500,000 & $\begin{array}{l}\text { Rensselaer Polytech. Inst., Troy, } \\
\text { N. Y. }\end{array}$ \\
\hline $700, \infty 00$ & $200, \infty 00$ & 400 & $42, \infty 00$ & 420,000 & La Salle College, Philadelphia \\
\hline 700,000 & $\cdots \ldots \ldots$ & $\cdots \cdots$ & $\cdots \cdots \cdots$ & $\ldots \ldots \ldots$ & U. of Richmond, Va. \\
\hline $650, \infty 00$ & 200,000 & $\cdots \cdots$ & ........ & $\ldots \ldots \ldots$ & Mills College, Oakland, Calif. \\
\hline 650,000 & 125,000 & $288+$ & $32, \infty 00$ & $\ldots \ldots \ldots$ & Principia College, Elsah, Ill. \\
\hline $600, \infty 00$ & 250,000 & 100 & $\ldots \ldots$ & $\ldots \ldots \ldots$ & General Theological Seminary, N. Y. \\
\hline $500, \infty 00$ & 300,000 & 550 & $5^{8,800}$ & 556,000 & $\begin{array}{l}\text { N. D. Agricultural College, Fargo } \\
\text { (completed) }\end{array}$ \\
\hline $500, \infty 00$ & 250,000 & 200 & $\cdots \cdots \cdots$ & $\ldots \ldots \ldots$ & Harpur College, Endicott, N. Y. \\
\hline $500, \infty 00$ & $200, \infty 00$ & 200 & $\ldots \ldots$ & $\ldots \ldots \ldots$ & Wabash College, Crawfordsville, Ind. \\
\hline 500,000 & 150,000 & 600 & 45,000 & $\ldots \ldots \ldots$ & $\begin{array}{l}\text { College of the Pacific, Stockton, } \\
\text { Calif. }\end{array}$ \\
\hline 500,000 & 150,000 & 200 & 8,228 & 269,896 & Rollins College, Winter Park, Fla. \\
\hline $500, \infty 00$ & $80, \infty 00$ & $150+$ & $\cdots \cdots$ & $\ldots \ldots \ldots+$ & College of St. Rose, Albany, N. Y. \\
\hline $\begin{array}{c}500,000 \\
\text { (very tentative) }\end{array}$ & $\cdots \cdots \cdots$ & $\ldots \ldots$ & $\ldots \ldots \ldots$ & $\ldots \ldots \ldots$ & U. of Santa Clara, Calif. \\
\hline 475,000 & $64, \infty 00$ & $35^{\circ}$ & 25,000 & $815, \infty 00$ & $\begin{array}{l}\text { Fairmount State College, Fairmount, } \\
\text { W. Va. }\end{array}$ \\
\hline 400,000 & $200, \infty \infty$ & 400 & & $\ldots \ldots \ldots+$ & Bethany College, Bethany, W. Va. \\
\hline $350, \infty 00$ & 125,000 & $225^{-250}$ & $15^{-18, \infty}$ & $\cdots \ldots \ldots$ & $\begin{array}{l}\text { North Central College, Naperville, } \\
\text { III. }\end{array}$ \\
\hline 310,000 & $100, \infty \infty$ & 250 & 19,200 & $\ldots \ldots \ldots$ & Lycoming College, Williamsport, $\mathrm{Pa}$. \\
\hline$\ldots \ldots \ldots$ & $100, \infty \infty$ & $\cdots \cdots$ & $\cdots \cdots$ & $\ldots \ldots \ldots+$ & St. Mary College, Xavier, Kansas \\
\hline 300,000 & I $10, \infty 00$ & 200 & $\cdots \cdots \cdots$ & $\cdots \cdots \cdots$ & Hampden, Sydney, Va. \\
\hline 300,000 & $100, \infty \infty$ & 264 & $\cdots \cdots$ & $\ldots \ldots \ldots$ & $\begin{array}{l}\text { Lowell Textile Institute, Lowell, } \\
\text { Mass. }\end{array}$ \\
\hline 300,000 & 100,000 & 150 & $\cdots$ & $\cdots \cdots \cdots$ & Conception Seminary, Conception, \\
\hline$\cdots \cdots \cdots$ & $60, \infty \infty$ & 250 & & . & $\begin{array}{l}\text { State Teachers College, Edinboro, } \\
\mathrm{Pa} \text {. }\end{array}$ \\
\hline & $60, \infty 00$ & 100 & 13,846 & & $\begin{array}{l}\text { S. W. Medical School, U. of Texas, } \\
\text { Dallas (now in temporary build- } \\
\text { ing) }\end{array}$ \\
\hline 288,000 & 40,000 & 260 & $\ldots \ldots$ & $\ldots \ldots \ldots$ & Oregon Coll. of Educ., Monmouth \\
\hline $275, \infty 00$ & .......... & ..... & ........ & $\ldots \ldots \ldots$ & E O C E Library, LaGrande, Oregon \\
\hline $265, \infty 00$ & $100, \infty \infty$ & 400 & $\cdots \cdots$ & $\cdots \cdots \cdots$ & $\begin{array}{l}\text { new Orleans Baptist Theol. Sem1- } \\
\text { nary, New Orleans, La. }\end{array}$ \\
\hline ........ & 95,000 & 600 & & $\cdots$ & $\begin{array}{l}\text { Middle Tennessee State College, } \\
\text { Murfreesboro, Tenn. }\end{array}$ \\
\hline $250, \infty 00$ & $100, \infty \infty$ & 200 & 17,500 & & $\begin{array}{l}\text { Western Maryland College, West- } \\
\text { minster, Md. }\end{array}$ \\
\hline 250,000 & $75^{-100,000}$ & 150 & 9,500 & $190-200, \infty 00$ & Seton Hill College, Greensburg, $\mathrm{Pa}$. \\
\hline 250,000 & 80,000 & 142 & 15,910 & $\ldots \ldots \ldots$ & Panhandle A. \& M. Goodwell, Okla. \\
\hline 228,000 & $100, \infty 00$ & 407 & $3^{8,}, 3^{85}$ & $\ldots \ldots \ldots$ & State U. of N. Y., Albany \\
\hline$\cdots \cdots \cdots$ & $50, \infty 00$ & 100 & $\cdots \cdots \cdots$ & $\cdots \cdots \cdots$ & $\begin{array}{l}\text { Western Theol. Seminary, Holland, } \\
\text { Mich. }\end{array}$ \\
\hline 205,000 & 45,000 & 115 & 4,900 & $\cdots \cdots \cdots$ & Concordia, St. Paul, Minn. \\
\hline 200,000 & I $50, \infty 00$ & 50 & $\cdots \cdots$ & $\cdots \cdots \cdots$ & Crozer Seminary, Chester, Pa. \\
\hline $\begin{array}{l}200, \infty 00 \\
200, \infty 00\end{array}$ & $100, \infty 00$ & 500 & $\cdots \cdots$ & $\cdots \cdots \cdots$ & Howard College, Birmingham, Ala. \\
\hline $200, \infty 00$ & 100,000 & 130 & $\cdots \cdots$ & $\cdots \cdots \cdots$ & $\begin{array}{l}\text { St. Paul's Polytech. Inst., Lawrence- } \\
\text { ville, Va. }\end{array}$ \\
\hline 200,000 & $60, \infty 00$ & 250 & $12, \infty 00$ & 105,000 & So. State College, Magnolia, Ark. \\
\hline 200,000 & $35, \infty 00$ & 50 & $\cdots \cdots$ & $\cdots \cdots \cdots$ & $\begin{array}{l}\text { Chicago Lutheran Theol. Seminary, } \\
\text { Maywood, Ill. }\end{array}$ \\
\hline 200,000 & $30, \infty \infty$ & 120 & $\cdots$ & . & $\begin{array}{l}\text { Connors State Agric. Coll., Warner, } \\
\text { Okla. }\end{array}$ \\
\hline
\end{tabular}

1 A blank indicates that no information was given on the questionnaire. 


\begin{tabular}{|c|c|c|c|c|c|}
\hline $\begin{array}{l}\text { Est. Cost } \\
\text { Inc. Equip. }\end{array}$ & $\begin{array}{l}\text { No. of } \\
\text { Vol. }\end{array}$ & $\begin{array}{l}\text { No. } \\
\text { Readers }\end{array}$ & $\mathrm{Sq} \cdot \mathrm{Ft}$ & $\mathrm{Cu} . \mathrm{Ft}$. & Library \\
\hline 175,000 & $30, \infty 00$ & 170 & 11,800 & $\cdots \cdots \cdots$ & $\begin{array}{l}\text { LaVerne College, LaVerne, Calif. } \\
\text { (completed) }\end{array}$ \\
\hline $172,03^{8}$ & $42, \infty 00$ & $\begin{array}{l}800 \text { ( } \text { size of } \\
\text { student body) }\end{array}$ & $\cdots \cdots$ & 186,750 & Southwestern College, Winfield, Kan. \\
\hline $160, \infty 00$ & $75, \infty 00$ & 150 & 10,266 & 104,236 & Elizabethtown College, $\mathrm{Pa}$. \\
\hline $150, \infty 00$ & $50, \infty 00$ & 120 & 8,000 & $80, \infty 00$ & Hillsdale College, Hillsdale, Mich. \\
\hline $120, \infty 00$ & $100, \infty$ & I 30 & $\cdots \cdots$ & $\cdots \cdots \cdots$ & $\begin{array}{l}\text { St. Paul's Polytech. Inst., Lawrence- } \\
\text { ville, } \mathrm{Va} \text {. }\end{array}$ \\
\hline $100, \infty 00$ & $100, \infty 00$ & 200 & & $\cdots \cdots \cdots$ & $\begin{array}{l}\text { S.W. Bible Institute, Waxahachie, } \\
\text { Tex. }\end{array}$ \\
\hline $73, \infty 00$ & $30, \infty$ & 96 & 4,920 & $\ldots \ldots \ldots$ & York College, York, Neb. \\
\hline $50, \infty 00$ & $\ldots \ldots \ldots$ & $\cdots \cdots$ & $\ldots \ldots$ & $\ldots \ldots \ldots$ & McPherson College, Kan. \\
\hline $50, \infty 00$ & $1 \infty 0, \infty$ & 150 & $\ldots \ldots$ & $\cdots \cdots \cdots$ & $\begin{array}{l}\text { Gammon Theol. Seminary, Atlanta, } \\
\text { Ga. }\end{array}$ \\
\hline$\ldots \ldots \ldots$ & 25,000 & 100 & $\ldots \ldots$ & $\ldots \ldots \ldots$ & Siena College, Memphis, Tenn. \\
\hline$\ldots \ldots \ldots$ & $15-20,000$ & 100 & $\ldots \ldots$ & $\ldots \ldots \ldots$ & Ferris Institute, Big Rapids, Mich. \\
\hline
\end{tabular}

1 A blank indicates that no information was given on the questionnaire.

Since our study plans to deal only with separate buildings, more information should be obtained from the other 846 libraries that operate in a building occupied jointly with some other agency on the campus. None of the information here pertains to those libraries.

Question 2 deals with the year of original construction, the number per year, and shows that the oldest library building still in service was built in $184 \mathrm{I}$. High years in library construction are: 1945-50, IO3 libraries; 1935-40, 90 libraries; 1925-30, 91 libraries, etc. A total of 573 buildings were built from $184 \mathrm{I}$ to $195 \mathrm{I}$, according to the questionnaires.

Question 3 reads: "If your building was originally built for some other purpose, check here —_." Ninety checked, indicating the possibilities of a study on what problems have been encountered in connection with converting some building designed for another purpose into a library.

Question 4 deals with additions built to the original building. 138 have had additions built.

Question 5 stated, "How many volumes could your present building accommodate if it were completely filled?" The answers range from $3,500,000$ down to 3,500 , with the greatest frequency from 100,000 to 200,000 . It is of interest that II of the libraries reporting have a capacity of 1,000 ,ooo or over, and 32 more have a capacity of between one-half million and one million volumes.

Question 6 asks: "Is your library completely or almost filled?" 267 reported "yes," and 301 reported "no." Although 267 reported that they were filled and only IO2 reported they planned to build before 1960 , it must show that many more will have to build soon or be heavily overcrowded before 1960 .

Questions 7 and 8 related to seats in the library as related to the size of the student body, and whether or not the seating was ample, barely ample, or insufficient. Some interesting information was brought out here, and the Committee plans to analyze this information in the near future.

Questions 9 and 1o relate to new buildings before 1960 , and this information is tabulated herein.

Question II shows that II4 libraries are planning to construct an addition, and 28 plan to construct a departmental library, and II plan some other construction, pre- 
sumably adding stacks within a building already built.

Question 12 stated, "If the above questions do not fit your situation, please explain and describe your building problems and plans below." No accurate count has been made, but a safe guess is that com- ments on problems were made on two-thirds of these that have separate buildings. The Committee has no definite plan for tabulating these, but perhaps will turn them over to some library school for a worth while term report.

\section{Library Research in Progress}

In its October issue College and Research Libraries, acting in conjunction with the $\mathrm{Re}$ search Planning Committee of the A.C.R.L., will publish a list of "Library Research in Progress." Only such research that bears directly on the problems of college and research libraries will be included in the list.

Except for those who are preparing theses in library schools, all librarians engaged in such research as is described above are invited to participate in this listing. Each item sent to the editor should include the title of the research in progrss, and the name and library address of the author.

\section{Dayton Collection to West Virginia}

A gift to West Virginia University of the book collection of the late Arthur S. Dayton of Charleston has been made by his widow, Ruth Woods Dayton.

The 7,000-piece collection, famed for its Shakespearean and other volumes dealing with the Elizabethan period, was unveiled to the public at a reception which marked the first use of the new "Rare Book Room." It is located in the addition to the library, which, completed this year, doubles the book capacity and increases considerably the student reading space.

Included are copies of all four Folios, the most highly-prized and sought-after of all editions of Shakespeare. The First Folio, initially printed edition of the Bard's collected plays, appeared in 1623 and is the greatest rarity. The Second Folio, printed in 1632 , is a rare Smethwick variant, while the Third Folio, 1664, was formerly the property of Julia Marlowe, and has the joint bookplate of the famous Shakespearean actress and her husband, E. H. Sothern. The Fourth Folio, I664, completes the quartet.

In addition to the Tonson quarto editions of the separate plays, issued in 1734 and 1735 , the Shakespeare group includes rare examples of subsequent collected editions of the plays and poems-approximately 65 different editions-ranging in date from 1709 to the pres- ent, and representing the editorship of such eminent figures as Alexander Pope, Samuel Johnson, James O. Halliwell, and Furness. A serious student of Shakespeare and his times, Mr. Dayton collected rare editions of various chronicles of the period and hundreds of volumes of critical and biographical studies, not only of the poet but of his contemporaries as well.

One of the oldest volumes in the Dayton collection is the "Nuremberg Chronicle," printed by Anton Koberges in 1493. Considered one of the finest works of the 15th century, it contains nearly 2,000 woodcuts by Wolgemuth and Pleydenwurff. The text of the book is a full chronicle of the world's history from its creation to the time the work was printed.

Included also are first editions of Milton's "Paradise Lost" and "Paradise Regained," the First Folio edition of Ben Jonson's works, all of Jane Austen's novels, first of works by Dickens, Thackeray, Tennyson, Kipling, Cotton Mather, and other celebrated authors. There are more than 200 volumes of Sir Walter Scott's works, including all of the Waverly novels in their original bindings.

In American literature, the Mark Twain collection is probably the most important. It contains almost 300 items, including first editions of all of Twain's writings. 